д.и.н., профрессор, Ангарский государственный технический университет, e-mail:kafobn@angtu.ru

Тихонова Ангелина Евгеньевна, обучающийся, Ангарский государственный технический университет, e-mail:lina_tikhonova@icloud.com

МИГРАЦИОННАЯ ПОЛИТИКА ГОСУДАРСТВ ЕВРОСОЮЗА

Savchuk N. V., Tikhonova A. E.

\title{
MIGRATION POLICY OF THE EU STATES
}

\begin{abstract}
Аннотация. Рассмотрены причины усиления миграционных процессов. Дана характеристика моделей миграционной политики государств Евросоюза

Ключевые слова: Евросоюз, миграционная политика, проблемы адаптации мигрантов.

Abstract. The causes of reinforcement of migration processes are considered. The characteristic patterns of migration policy of the EU States are given.
\end{abstract}

Keywords: European Union, migration policy, problems of adaptation of migrants.

В современный период миграционные процессы приобрели черты глобального явления, которое называют новым «великим переселением народов», способным изменить облик государств и континентов. Статистические данные свидетельствуют о том, что в первом десятилетии XXI столетия миграция населения росла в два раза быстрее, чем в предыдущие десятилетия. Максимальные показатели пришлись на 2015 г. В государства Европейского Союза иммигрировали 4,7 миллиона человек. Наибольшее количество оказалось в Германии, Великобритании и Франции. Причем значительная их часть - мусульмане. Только по официальной статистике количество мусульман в Германии составляет свыше 3 млн. человек, в Великобритании - 1,5 млн., во Франции - более миллиона человек. А к 2050 году их количество в Евросоюзе может составить $50 \%$ населения [2, с. 277].

Среди современных тенденций международной миграции можно выделить следующие: рост нелегальной трудовой миграции; рост вынужденной миграции из-за вооруженных конфликтов; рост демографической значимости международной миграции для тех стран, где сокращается численность коренного трудоспособного населения; качественные изменения в потоке мигрантов, связанные с увеличением количества мигрантов с высоким уровнем образования и профессиональной подготовки; глобализация мировых миграционных потоков, выражающаяся в том, что определились страны с преобладанием эмиграции, либо иммиграции.

Масштабность этого явления сделала необходимым для государств, принимающих мигрантов, разработать механизмы управления этими процессами, чтобы обеспечить баланс интересов коренного населения и мигрантов. Миграционная политика представляет собой совокупность принципов, законодательных норм и социальных программ. В государствах Евросоюза сложись разные модели миграционной политики и адаптации мигрантов. При их разработке 
правительства исходили из сложившихся либерально-демократических ценностей и прав человека.

Модель ассимиляции, используемая в Германии, и Франции заключается в формировании однородной структуры общества, хотя вплоть до начала XXI столетия придерживались этнокультурной концепции нации. В Германии провозглашен принцип «конституционного патриотизма», т.е. признание законов и немецкого языка, обеспечивающего взаимосвязь всех жителей страны. В Конституции Франции главным в признании гражданства является проживание на ее территории без различия расы или религии.

Модель сосуществования разных этнических культур применяется в большинстве европейских государств - Великобритании, Нидерландах, Бельгии, Швеции, Дании. В Великобритании идея толерантности исторически укрепилась еще в период, когда она являлась колониальной империей. В XXI В. гражданство может получить небританец, проживающий постоянно в стране. Стратегия интеграции иммигрантов осуществляется через этнические общины.

Несмотря на комплекс принимаемых мер адаптация мигрантов в новых условиях происходила сложно из-за разных культур и религий, представлений об общественном устройстве и законодательстве. Применяемые модели, как и идея мультикультурализма не выдержали проверку временем, что ярко проявилось в период миграционного кризиса 2016-2017 гг. Большинство граждан стран-членов ЕС не одобряли либерализацию миграционной политики, рассматривали иммигрантов как угрозу для общества. Наибольший протест выразило коренное население Греции, Швеции, Италии [1].

Ужесточение миграционной политики в 2017 г. выразилось в том, что в 8 государствах из 26 членов Шенгенской зоны на внутренних границах был восстановлен пограничный контроль; построены заборы, чтобы не допустить проникновение мигрантов на свою территорию; созданы лагеря для беженцев за пределами Евросоюза; осуществлялась борьба с нелегальными перевозчиками мигрантов и др.

Тем не менее, эти меры не гарантировали выхода европейских государств из миграционного кризиса, а, следовательно, сохраняются территориальные, экономические, социальные, политические угрозы.

\section{ЛИТЕРАТУРА}

1. Евросоюз и терроризм: жизнь в условиях постоянной угрозы [Электронный ресурс] // Наука и образование против террора: [сайт]. URL: http://scienceport.ru/ (дата обращения: 1.03.2019).

2. Петрищев В.Е. Что такое терроризм или Введение в террорологию. М.: КРАСАНД, 2018. 464 с.

3. Хенкин С.М., Кудряшова И.В. Интеграция мусульман в Европе: политический аспект // ПОЛИС. 2015. №2. С. 137-155. 